NBER WORKING PAPER SERIES

US TRADE AND WAGES:

THE MISLEADING IMPLICATIONS OF CONVENTIONAL TRADE THEORY

\author{
Lawrence Edwards \\ Robert Z. Lawrence \\ Working Paper 16106 \\ http://www.nber.org/papers/w16106 \\ NATIONAL BUREAU OF ECONOMIC RESEARCH \\ 1050 Massachusetts Avenue \\ Cambridge, MA 02138 \\ June 2010
}

This paper is based on research undertaken for a book Rising Tide: Is Growth in Emerging Markets Good for the United States to be published by the Peterson Institute for International Economics. We thank the Sloan Foundation, The Center for International Development at Harvard, ERSA, and the National Research Foundation of South Africa for financial support. Any opinion, findings and conclusions or recommendations expressed in this material are those of the authors and do not necessarily reflect the views of the funders or the National Bureau of Economic Research. We are indebted for research assistance to Pandey Bibek and Sounman Hong.

NBER working papers are circulated for discussion and comment purposes. They have not been peerreviewed or been subject to the review by the NBER Board of Directors that accompanies official NBER publications.

(C) 2010 by Lawrence Edwards and Robert Z. Lawrence. All rights reserved. Short sections of text, not to exceed two paragraphs, may be quoted without explicit permission provided that full credit, including $(\odot)$ notice, is given to the source. 
US Trade and Wages: The Misleading Implications of Conventional Trade Theory

Lawrence Edwards and Robert Z. Lawrence

NBER Working Paper No. 16106

June 2010

JEL No. F11,F16,J3,J31

\begin{abstract}
Conventional trade theory, which combines the Heckscher-Ohlin theory and the Stolper-Samuelson theorem, implies that expanded trade between developed and developing countries will increase wage inequality in the developed countries. This theory is widely applied. It serves as the basis for estimating the impact of trade on wages using two-sector simulation models and the net factor content of trade. It leads naturally to the presumption that the rapid growth and declining relative prices of US manufactured imports from developing countries since the 1990s have been a powerful source of increased US wage inequality.

In this study we present evidence that suggests the presumption is not warranted. We highlight the sensitivity of conventional theory to the assumption of incomplete specialization and find evidence that is not consistent with it. Since 1987, although US domestic relative effective prices in industries with relatively high shares of manufactured goods imports from developing countries have declined, effective unskilled worker-weighted prices have actually risen relative to skilled worker-weighted prices. If anything, this suggests pressures for increased wage equality. Also in apparent contradiction to theory, the (six-digit North American Industry Classification System [NAICS]) US manufacturing industries with high shares of manufactured imports from developing countries are actually more skill intensive than the industries with high shares of imports from developed countries. Finally, applying a two-stage regression procedure, we find that developing-country import price changes have not mandated increased US wage inequality. While these results conflict with standard theory, they are easily explained if the United States and developing countries have specialized in products and tasks that are highly imperfect substitutes. If this is the case, the impact of increased trade with developing countries on US wage inequality is far more muted than standard theory suggests. Also methodologies such as the net factor content of trade using US production coefficients and simulation models assuming perfect substitution between imports and domestic products could be highly misleading.
\end{abstract}

Lawrence Edwards

School of Economics

Cape Town University

Cape Town Rep of South Africa

Lawrence.Edwards@uct.ac.za

Robert Z. Lawrence

JFK School of Government

79 JFK Street

Cambridge, MA 02138

and Peterson Institute for International Economics

and also NBER

robert_lawrence@harvard.edu 


\section{US Trade and Wages: The Misleading Implications of Conventional Trade Theory}

Conventional trade theory provides a powerful framework for thinking and testing the links between trade and wages. The Heckscher-Ohlin theory predicts that patterns of trade reflect relative factor endowments. In a two-good, two-factor model with skilled and unskilled labor, developing countries with relatively abundant endowments of unskilled labor will specialize in the production of unskilled labor-intensive products. If these countries liberalize, therefore, they will increase their relative demand for skillintensive products. To pay for these they will have to export additional quantities of unskilled labor-intensive products. Together these forces will reduce the world relative price of unskilled labor-intensive products. The domestic relative price of unskilledintensive products will also decline if developed countries reduce their tariffs on imports from developing countries.

The theory developed by Stolper and Samuelson (SS) (1941) in turn provides the link between product prices and factor returns. It shows, in the case of two goods and two factors, that a decline in the relative price of a product reduces both the relative and absolute earnings of the factor used relatively intensively in its production. ${ }^{2}$ In combination, therefore, this Heckscher-Ohlin, Stolper-Samuelson framework (HOSS) implies that expanded trade with developing countries due to liberalization could be associated with increased wage inequality in their more developed counterparts. ${ }^{3}$

In this framework, the product prices of traded goods drive factor prices throughout the economy. In small, price-taking countries changes in relative factor supplies have no effect at all and in larger countries supply changes have an impact only

\footnotetext{
${ }^{2}$ Factor intensity is defined by the factor shares in total costs. If there are two factors: skilled $(s)$ and unskilled labor $(u)$, and two goods: a skilled labor-intensive good $x$ and an unskilled labor-intensive good $y$, there is a one-to-one relationship between the relative prices of the goods and the relative wages of skilled $(W S)$ and unskilled $(W u)$ workers. Using a * to indicate proportional rates of change, and $S x$ and $S y$ denote the shares of skilled labor in the production cost of $x$ and $y$ respectively then:$$
P x^{*}-P^{*} y=(S x-S y)\left(W s^{*}-W u^{*}\right)
$$

The theory can also explain the impact of productivity changes on factor prices, assuming given prices. In this case, an increase in productivity in an industry raises the relative return to the factor used relatively intensively.

${ }^{3}$ More generally, because it predicts who wins and who loses from trade, the theory has been useful for explaining political positions and attitudes to trade. For an application of Stolper-Samuelson to international public opinion see Mayda and Rodrik 2002 and Alt and Gilligan 1999.
} 
to the extent they affect world prices of traded goods. ${ }^{4}$ Since Stolper-Samuelson assumes that skilled and unskilled labor are perfectly mobile, its predictions are extremely powerful because mobility implies that the forces affecting the wages of workers producing the goods that compete directly in international trade have similar effects on workers who produce nontraded goods and services in the rest of the economy. Richard Freeman (1995) memorably captured the power of this process in the title of his survey paper on the links between trade and wages when he asked "Are your wages set in Beijing?"

There are, to be sure, other frameworks that feature trade in explaining wage behavior. They include theories that assume that factors of production are sector specific and those that consider trade's impact on worker bargaining power. But since these theories allow for workers with similar skill levels to earn different wages depending on their industry of employment, they predict that the effects of trade occur mainly in the industries that produce particular traded goods and services and are less useful in explaining economywide wage trends.

\section{Empirical Methods}

HOSS theory is also attractive because it can be applied quite easily. This has made it the centerpiece of empirical studies on the impact of trade on income inequality. There are a number of different empirical approaches that can be rigorously justified. ${ }^{5}$ One is to estimate wage changes due to trade by calculating the net-factor content of trade. This approach reflects the insight that, in conventional framework, trade and factor movements are substitutes. Trade is equivalent to adding to the economy's factor supplies

\footnotetext{
${ }^{4}$ In the case of countries too small to affect world prices, changes in domestic factor supplies simply shift the composition of output. If a country experiences an increase in the supply of unskilled labor, for example, these workers are absorbed into the labor force not by a change in wages but by an increase in the output of the unskilled labor-intensive industry and a reduction of output in the skill-intensive sector.

${ }^{5}$ The most straightforward versions identify the impact of trade with the prices of traded goods and explore directly whether these prices have moved in a way that would favor skilled or unskilled workers. But this is a considerable oversimplification since global prices of traded goods are not independent causes but reflect many influences such as changes in global factor endowments, trade policies, technologies, and preferences. Technically, international trade is an endogenous variable (Deardorff and Hakura 1994).
} 
the factors contained in imports, and subtracting from the supplies the factors contained in exports. Deardorff and Staiger (1988) provided a rigorous theoretical justification for this application. They showed that using net-factor content approach to estimate wage effects implicitly involves comparing two equilibriums under conditions of selfsufficiency.

The second way to isolate the independent determinants of traded goods prices is to build small general equilibrium simulation models of relative wage determination (e.g., Krugman 1995 and Cline 1997). These models can then be used to estimate the likely wage impact of exogenous shocks such as liberalization and/or growth in developing countries that will influence relative wages by affecting trade flows. Here the challenge is coming up with the correct parameters and calibration of the models.

Econometric techniques less dependent on the HOSS theory can also be used. One of these pioneered by Feenstra and Hanson (1999) and applied by others (e.g., Haskel and Slaughter 2001, 2003) involves econometric estimation in a two-step procedure. First, the effect of trade on product prices is estimated, and in a second step, estimates are made of the mandated wage changes that would result from the price changes due to trade predicted in the first stage.

This combination of powerful theoretical predictions and easy empirical applicability has made the HOSS alluring for work on the links between trade and wages. The HOSS paradigm leads to the presumption that increased imports and declining relative prices of manufactured imports from developing countries will lead to substantial increases in US wage inequality. But we will argue that despite its virtues, the HOSS framework can be highly misleading because it ignores the role of complete specialization.

In the first section of this paper we emphasize the key role played by the assumption that domestic and imported goods are close substitutes. We note how its violation could lead to very different outcomes. In the second section we describe several studies of recent US experience that do not support the view that the surge in US manufactured imports from developing countries has increased wage inequality in a major way. In the third section we explore the behavior of the relative prices of US manufactured goods and find that domestic US price behavior has not been compatible 
with the HOSS paradigm. We show that while the US industries with high shares of developing-country imports have experienced declining relative prices, the presumption-based on the Heckscher-Ohlin theory that these US industries are intensive in unskilled labor is not borne out by the data. Indeed, we find that effective US domestic prices have actually moved in a way that would justify greater wage equality!

It is possible that although import prices have exerted pressures on relative wages, there have been other sources of price changes that have offset them. Absent trade, perhaps wage inequality might have fallen. In section four, therefore, we apply the twostep procedure of Feenstra and Hanson (1999) and isolate the pressures on wages specifically due to import prices from developing countries. We find that these influences were negligible. Even without the effects of imports, therefore, we conclude that over the past decade, US relative wages would not have been very different.

All told, the presumption that declining relative prices of imports from developing countries provided pressures for increased US wage inequality is not warranted. We conclude that HOSS theory and the empirical methods that draw on it are inappropriate when it comes to anticipating and explaining the impact of US trade with developing countries on wage inequality because US domestic production has become highly specialized.

\section{Section I: The Key Role of Incomplete Specialization}

Empirical applications of any theory will only yield the correct answer if the assumptions used in the theory are valid. ${ }^{6}$ While appealing in its simplicity, the assumptions required to apply the SS theory using these methods are extremely restrictive. ${ }^{7}$ The most important of these is nonspecialization: i.e., the assumption that the same goods that are imported are also produced at home. Domestic factor prices will depend only on the prices of goods that are actually produced domestically and if an imported product is not produced

\footnotetext{
${ }^{6}$ The assumptions are so severe that the original Stolper and Samuelson paper was first rejected for publication as a theory by the editors of the American Economic Review who acknowledged that it was a "beautiful theoretical performance" but felt that "i $[\mathrm{t}]$ does not have anything to say about any real life situations with which the theory of international trade has to concern itself."

${ }^{7}$ As noted by Henry Thompson (2007): "With more than the minimal number of inputs, there is no simple theoretical prediction regarding the wage." It can be shown, however, that at least one factor will be made worse off by trade.
} 
locally, its prices will not directly affect factor prices. Specialization could either occur because some homogeneous imported products are not produced domestically or because imports and domestic goods are imperfect substitutes.

This is not simply a theoretical possibility. Schott (2003) has emphasized the empirical problems of applying the "single-cone" version of the Heckscher-Ohlin theory which requires that all countries produce all types of goods. He demonstrates how that framework fails to explain actual trade patterns. On the other hand, he does find empirical support for a multicone equilibrium in which countries specialize in the subset of goods that are most suited to their endowments.

If a country is "fully specialized," for example, and the goods produced at home all differ from those that are imported the strong predictions of Stolper-Samuelson disappear. Relative factor supplies will affect factor prices and import prices will impact domestic product and factor prices only indirectly via their effects on demand for domestic goods. ${ }^{8}$ As Whalley and Abrego (2000) show, if rather than infinite (i.e., perfect substitutes) the elasticity of substitution between imports and domestic products is unity—as many empirical studies suggest it might be — changes in import prices will not influence domestic product or factor prices at all!

Again this is not simply a theoretical possibility. Many empirical trade models that are used to simulate trade policies adopt the so-called Armington assumption that products have distinctive national attributes and thus are imperfect substitutes. If countries are fully specialized as suggested by the imperfect substitutes model — aside from these demand channel effects - when import prices fall, all domestic producers could gain and if the price declines are concentrated in products that are disproportionately consumed by the poor, real (as opposed to relative) income differentials could actually narrow (Broda and Romalis 2008).

Once it is acknowledged that changes in specialization patterns are taking place, it could require changes in the methods used to estimate the impact of trade. Adrian Wood

\footnotetext{
${ }^{8}$ Relative factor supplies will matter for factor prices if an economy is fully specialized as in this example, or more generally when the number of factors is greater than the number of tradable goods that are produced at home.

${ }^{9}$ If the elasticity of substitution is less than unitary, the sign of the effect actually changes: lower import prices of unskilled-labor products would increase domestic prices of domestic substitutes! The effects would be present with the expected signs if the elasticity is greater than unitary but would be far more muted than assumed in the case of perfect substitutes.
} 
(1994) argued that the early effects of trade on the wages of unskilled workers were larger than most of the existing studies had implied because while originally developed countries had produced unskilled labor-intensive products, specialization had evolved to the point that developed and developing countries produced different kinds of products. This meant that when studies used input-output coefficients taken from developed countries to estimate the impact of trade they were seriously underestimating the degree to which imports from developing countries had previously displaced unskilled labor in developed countries. ${ }^{10}$

But while Wood argued that the initial wage impact of replacing domestic production with imports from developing countries was underestimated, he also pointed out that once the adjustment had been made, the pressures for increased inequality would diminish. Thus, his view (Wood 1995) also led him to reject the forecasts of those who argued that the impact of trade on the relative wages of unskilled workers in developed countries would become increasingly pronounced over time (e.g., Sachs and Shatz 1994 and Krugman 2007). ${ }^{11}$ Instead, he argued they would diminish because additional downward movements in the prices of most unskilled labor-intensive products would not put pressures on the wages of unskilled workers in developed countries once they no longer produced such goods. ${ }^{12}$ We will argue below that Wood was prescient.

\section{Vertical Specialization}

Specialization could also be vertical. Grossman and Rossi-Hansberg (2008) identify three channels through which imported intermediate inputs could affect domestic factor prices. Two are familiar. The first is the relative price effect. If perfect substitutes for imported intermediate products are also produced at home, the conventional theory would still predict an impact on relative wages - though the effects would be transmitted within rather than between industries. This operates like the conventional Stolper-Samuelson

\footnotetext{
${ }^{10}$ For a critique of Wood, see Lawrence 1996.

${ }^{11}$ Wood (1995, pg. 77) wrote, "I do not expect unskilled workers in developed countries to be much hurt by even major new entry into the world market for low skill-intensive manufacturers, simply because these goods are no longer produced in developed countries. The entry of China and India, pushing down the world prices of these goods, will benefit developed-country workers, skilled and unskilled alike."

${ }^{12}$ Feenstra and Hanson (1996) model a similar process in the context of an economy that has noncompeting imports.
} 
effect. The second is what they call the labor-supply effect. This occurs when there is displacement of activities when patterns of specialization change in economies in which relative supplies can also affect factor prices. If, for example, labor-intensive tasks were once undertaken at home and these move offshore, the relative supply of labor could rise and wages could fall. This effect can be estimated using measures of the factors that were actually displaced.

They also uncover a third effect, the productivity effect that operates when cheaper imported inputs increase the profitability of domestic assembly operation in which they are used. Cheaper imported auto parts for example, could increase the profitability of auto assembly. This effect operates exactly like sector-biased productivity growth and will raise the return to the factor used relatively intensively in assembly. ${ }^{13}$ Imports and domestic production are actually complements in this case rather than substitutes.

\section{Heterogeneous Firms}

Recent theoretical literature on product specialization within industries as well as within firms provides additional insights. Bernard, Redding, and Schott (2007) develop a multifirm model that embodies heterogeneous firms in a model of comparative advantage. Trade liberalization induces a reallocation of resources both within and across industries and countries. This leads to the emergence of more productive firms and exit of relatively inefficient firms in all industries, but particularly in comparative advantage industries. The productivity effect of this reallocation creates additional welfare gains from classical trade theory, but most importantly for our purposes, dampens the real and relative wage losses of scarce factors. ${ }^{14}$

More recently $(2009,2010)$, these authors have focused on multiproduct firm models where firms differ with respect to the number of products they produce and export and their productivity levels. Trade liberalization causes the weakest firms to exit,

\footnotetext{
13 This effect has also been recognized by Feenstra and Hanson (1999) who note that offshoring will show up in the industry aggregate production function as a change in total factor productivity.

${ }^{14}$ Real wages of the scarce factor may even rise in response to the productivity improvements. Additional welfare gains arise from increases in the varieties of products produced.
} 
and within surviving firms the least profitable products are dropped. Although their 2009 multiproduct model is not set up to look at wage inequality, the within-firm increases in productivity in response to product switching is likely to enhance aggregate real wage gains from liberalization.

For our purposes, what is important is that relaxing the strict association between products that are perfect substitutes and the factor intensities that are associated with them makes the merging of the Heckscher-Ohlin and Stolper-Samuelson theories increasingly less tenable. If imports are not produced domestically, using domestic industry input coefficients could be highly misleading. If specialization is complete and imports and domestic goods are imperfect substitutes, transmission from import prices to domestic factor prices is weaker than the theories assume and other considerations such as demand elasticities and relative factor supplies come into play. In addition with vertical specialization, the Stolper-Samuelson forces could still operate on domestic producers but they could also be offset or even countermanded if domestic production and imports are complements rather than substitutes. ${ }^{15}$ Finally, adjustments by firms within industries in response to import competition can dampen the real and relative wage losses of scarce factors.

\section{Section II: Studies of Recent US Experience}

In the 1980s wage inequality was a major contributor to increased income inequality in the United States. The earnings of workers with skills by all measures (education, occupation, experience) outpaced those with less skill by all of these criteria. Since this inequality occurred at the same time as an expansion in US trade with developing countries, it was quite natural that researchers considered whether trade could provide the explanation. Given the power of the theory and the tools available to apply it, it is no surprise that economists used their toolkits to estimate the impact of trade and wages in this framework. The approaches did have some explanatory power, but the consensus seemed to be that while trade was a factor, other forces were more powerful. As noted by

\footnotetext{
${ }^{15}$ Bernard, Jensen, and Schott (2006), for example, find that some US firms have responded to import competition by investing more in equipment and technology.
} 
William Cline (1997) in his comprehensive survey, "a reasonable estimate based on the literature would be that international influences contributed about 20 percent [italics added] of the rising wage inequality in the 1980s." "Causes such as skill-biased technological change, in combination with a slowdown in the growth rates of the supply of college graduates were given a greater role (Goldin and Katz 2007). In addition, other factors such as immigration, declining unions, and a change in norms were pointed to as contributing factors.

Through the 1990s, however, US trade with developing countries expanded very rapidly and by 2005 reached over 6 percent of US GDP. By then the value of nonoil US imports from developing countries had actually surpassed the value of imports from industrial countries. In addition, the prices of manufactured imports from developing countries declined dramatically relative to the prices of manufactured imports from developed countries. These developments raised the possibility that the effects of trade could have become much larger.

In 2007 in several newspaper columns, Paul Krugman (2007) drew attention to this development

"It's no longer safe to assert that trade's impact on the income distribution in wealthy countries is fairly minor. There's a good case that it is big, and getting bigger.... It's clear that applying the same models to current data that, for example, led William Cline of the Peterson Institute to conclude in 1997 that trade was responsible for a 6 percent widening in the collegehigh school gap would lead to a much larger estimate today."

If this conjecture is correct, the implications could be profound. Skilled and unskilled workers in the United States are generally distinguished in practice either by their occupations or their educational attainment (see box 1). Unskilled workers are typically those classified as production workers or those with less than a college degree. Skilled workers are those in supervisory occupations or those with a college degree or

\footnotetext{
${ }^{16}$ In his own work based on simulations, Cline (1997, pg. 144) concludes that "a third [italics added] of net increase in the skilled-unskilled ratio from 1973-93 was attributable to trade and an additional one-ninth was attributable to immigration."
} 
more. By either these occupation or education measures almost 70 percent of US workers are considered to be unskilled. If the view expressed by Krugman is justified, therefore, even if beneficial in the aggregate, trade with developing countries could be reducing living standards for the vast majority of US workers! Moreover policies such as trade adjustment assistance that deal only with displaced workers would be seriously deficient in compensating the losers.

Surprisingly, given these implications, relatively few studies have actually examined the more recent data. One possible reason for the paucity of recent studies is that since the early 1990s and especially after 2000, as emphasized by Lawrence (2008), the evidence of increased wage inequality along the lines of skill is more mixed than it has been earlier. ${ }^{17}$ Moreover those studies that have been done have not proven there are large effects.

One reason is that there has also apparently been a rise in the estimated skill intensity of imports based on US input data. Mishel, Bernstein, and Allegretto (2007, table 3.30 , pg. 175) report on a study that uses a net factor content approach to estimate job displacement. ${ }^{18}$ This study estimates that job displacement due to trade between 2000 and 2004 was 1.9 million - about the same as the 1.8 million estimated as displaced between 1979 and 1989. But the composition of displacement was very different. In particular, in the 1980s the job displacement was concentrated among less skilled workers: 12.2 percent of those displaced were college graduates, and 28 percent had less than high school education. Displacement after 2000 was very different: 21.3 percent of the displaced were college graduates - a proportion not very different from their 25.6

\footnotetext{
${ }^{17}$ Krugman (2008) and Lawrence (2008) have a difference of opinion on whether in fact wage inequality actually did increase in the United States, particularly after 2000. Unlike the 1980s, in which almost every possible classification of wages by skill (occupation, education, experience, 10th, 50th and 90th percentiles) shows a rise in inequality, after 2000 the picture is at best very mixed. While the relative wages of production workers had a strong declining trend through 2000, in 2008 they were at levels that were similar to those in 1997. Similarly, the declines in the relative earnings of high school to college graduates between the late 1990s and 2007 were relatively small. For example in 2007 the ratio of full-time earnings of male college graduates relative to male high school graduates was just 1.5 percent higher than in 1997 . There is ample evidence of increased income inequality in the United States over the past decade, but as discussed in Lawrence (2008) this was associated with high profit shares and earnings of the super rich, rather than changes in relative wages.

${ }^{18}$ Their work is based on Scott, Lee, and Schmitt 1997.
} 
percent share in the overall labor force. ${ }^{19}$ Given US nonfarm employment in 2000 of 130 million, this implies that the displacement due to trade reduced the employment ratio of high school to college graduates by three-tenths of a percent. If the elasticity of substitution between college and high school workers is unity, therefore, a decline of three-tenths of a percent in the relative wages of high school workers would be required to reemploy these displaced workers. Thus the net factor approach suggests that more recent trade has not had a major impact on recent US wage inequality.

Krugman (2008), however, expresses skepticism at these estimates of modest effects. He argues that the factor content coefficients are subject to aggregation bias and could miss the important effects if developing countries specialize in unskilled laborintensive intermediate product niches. ${ }^{20}$ Aggregation bias is, however, not an issue for the methodology, which uses simulation models using calibrated rather than estimated parameters. Bivens (2007) updated the simulation model developed by Krugman (1995) himself. These simulation models involve simply assuming that all imports from developing countries are unskilled labor-intensive and using plausible coefficients for skill intensity. This application suggests that increased US trade with developing countries between 1995 and 2006 boosted the US wage skill premium by just 2.1 percent (log points.) Lawrence Katz (2008), commenting on Krugman (2008), points out that the Bivens estimate implies that about 15 to 19 percent of the increase in the 26 percent long point increase in the college wage premium from 1980 to 2006 can be ascribed to trade. Apparently adding in data from the recent experience using this methodology does not materially affect the results obtained in the earlier studies.

Bivens's estimate is important since it presents an upper bound because it probably overstates the effects of developing-country trade on US unskilled wages for five reasons. First, it assumes that that all of the goods imported from developing countries are perfect substitutes for domestic products. As we noted in the previous section, if imports and domestic goods are different products, the effects only operate on

\footnotetext{
${ }^{19}$ Lawrence (2008, pg. 40) similarly finds US industries with high import shares from developing countries also do not typically pay wages that are lower than those in the economy as a whole.

${ }^{20}$ Feenstra and Hanson (2000) explored the issue of aggregation bias using net-factor content to estimate the impact of trade on wages. They find that while trade increased the (relative supply) ratio of production to nonproduction workers by 5 percent, this proportion did not change much between 1982 and 1994. They conclude "It seems unlikely that the factor content of trade has been a driving force behind changes in wages"
} 
factor prices via the demand side and could be much smaller than he implicitly assumes by using the model.

Second, it ignores the intermediate inputs of skilled labor-intensive products contained in imports from developing countries. For example goods whose final assembly is in China may contain skill-intensive, value-added from countries like the United States or Japan. This leads to an overstatement of the unskilled-labor content of these imports.

Third, it ignores the possibility that US firms might have adopted more skillintensive technologies in their efforts to compete with developing-country products (factor intensity reversals). ${ }^{21}$ If US goods that compete with developing-country imports are actually skill intensive, declining import prices from developing countries would actually reduce, rather than increase, wage inequality.

Fourth, it ignores the possibility of the Grossman and Rossi-Hansberg (2008) productivity effect by which lower input prices of labor-intensive tasks outsourced from labor-intensive industries could raise the relative wages of unskilled workers.

Finally, there is reason to believe the assumed parameters overstate the skill differences in industries that are actually involved in US trade. Bivens follows Krugman (1995) and assumes that in the US export industry skilled workers are half the workforce and earn two-thirds of the wage income, whereas in the US import-competing industry skilled workers constitute only 20 percent of the workforce and earn a third of the income. ${ }^{22}$ In fact, as we will show below, these assumed differences are far larger than suggested by weighting US six-digit industry skill ratios by their actual shares in imports from developed and developing countries.

Econometric work provides corroborating evidence for the low impact of trade on US wage inequality. Nino Sitchinava (2008) has refined and updated the methodology used by Feenstra and Hanson (1999) to measure outsourcing more accurately. She finds a

\footnotetext{
${ }^{21}$ It should be noted, however, that the results are sensitive to the parameter that is assumed for the elasticity of substitution between skilled and unskilled labor. In Krugman's (1995) model this is set at one. As Cline (1997, pgs. 161-163) notes there is a large range of estimates in the literature, and parameters less than one would indicate larger wage effects.

${ }^{22}$ These do seem be reasonable assumptions to capture skill differences across US industries but they do not necessarily capture those involved in trade. In 2007, in industries in the most skill-intensive third of manufacturing employment, 46 percent of the workforce was nonproduction workers; in the third with the least skill-intensive industries, only 19 percent were nonproduction workers.
} 
role for both outsourcing and the adoption of computers on the skill-unskilled wage gap between 1989 and 1996. However, she concludes that "neither of these factors affects wages between 1997 and 2004." In sum, all three of these approaches imply that if there are effects on wages from developing-country trade recently, they are relatively modest.

\section{Section III Recent US Experience: Missing Links in the HOSS Paradigm}

In this section we explore whether declining relative prices of imports from developing countries have been associated with declining relative effective prices of unskilled laborintensive products. According to the HOSS, increased wage inequality increases in response to declining prices of imports from developing countries, which occurs because of three presumptions: (1) declining import prices put downward pressure on the relative domestic prices in US industries that produce close substitutes; (2) these downward movements in relative domestic prices are not offset by productivity changes and thus effective relative prices, which reflect both prices and productivity, also fall; and (3) these declining relative effective prices occur in industries that are relatively intensive in unskilled labor and therefore mandate lower relative wages for less skilled Americans.

We will show that since the early 1990s, the first two parts of this story seem to hold. The domestic relative prices in industries with relatively high shares of manufactured goods imports from developing countries have declined. In addition, while some of the decline is attributable to relatively faster productivity growth, the declines remain even when productivity growth is taken into account.

The problems for the HOSS story arise, however, because these effective price movements have not translated into declines in the relative effective prices of unskilled labor-intensive goods. Indeed, effective production worker-weighted prices have actually risen relative to nonproduction worker-weighted prices. Rather than mandating increased wage inequality, therefore, recent domestic price trends appear to require movements toward more equal wages.

The link is broken because Heckscher-Ohlin theory is a poor guide to the factor intensity of the US industries that are classified in the same categories as those with a high share of imports from developing countries. In apparent contradiction to the theory, 
the (six-digit NAICS) US manufacturing industries with high shares of manufactured imports from developing countries are actually more skill intensive than the industries with high shares of imports from developed countries!

One three-digit US industry (NAICS 334) — computers and electronics — plays a role in these unexpected results. NAICS 334 is an anomaly. It employs very high shares of skilled workers ${ }^{23}$ and has had extraordinary productivity growth and rapidly declining prices. Surprisingly, given these characteristics, developing countries dominate US imports of these products - their share was 74 percent in $2000 .{ }^{24}$ Moreover, these imports were relatively more important for developing countries. In 2000, for example, NAICS 334 products accounted for 34 and 16 percent of the value of manufactured imports from developing and developed countries respectively.

The movements in prices and productivity have been so large that when NAICS 334 is included in price and/or productivity measures it has a dominant effect. The larger weight given to the 334 industry when it comes to developing countries is an important reason that relative import prices from developing countries have fallen rapidly. It also helps explain why judged by US input coefficients manufactured imports from developing countries are relatively more skilled-labor intensive.

Dropping the computer sector from the data yields results that are somewhat more closely in line in with conventional expectations. But the Heckscher-Ohlin link is still absent: Even excluding NAICS 334, imports from developing countries are as skill intensive as imports from developed countries. Excluding NAICS 334, there have been some small declines in the relative US domestic prices of goods in which imports from developing countries have higher shares. And prior to 2000, these declines were not fully offset by relatively faster multifactor productivity growth. However, downward price pressures on the wages of unskilled workers are still not evident. Excluding the computer sector, the price and multifactor productivity behavior of unskilled labor-intensive

\footnotetext{
${ }^{23}$ The industries composing the sector are the most skill-intensive in manufacturing. There are sixteen 6 sixdigit industries in the 334 sector and eight 8 of these are in the top ten10. In 2002 these eight had production worker shares in employment ranging from 0.31 to 0.42 . Overall the average ratio for the entire 334 industry of 0.50 is equal to the 24th highest ranking, six-digit industry.

${ }^{24}$ In 2000, imports from developing countries accounted for 86 percent of total imports in computers, communications, and audio and video equipment respectively and 74 percent of imports in NAICS 334 overall.
} 
products is no different from that of skilled labor-intensive products. Even without computers and electronics, therefore, relative wage changes do not appear warranted.

\section{Prices}

Import prices appear to confirm the HOSS story. As shown in figure 1 between 1990 and 2008, the prices of manufactured imports from developing countries fell dramatically relative to prices of imports from developed countries. ${ }^{25}$ However, what matters for US wages are domestic prices and accordingly we consider the behavior of domestic valueadded prices and multifactor productivity.

We have data from 1987 to 2006 for all 88 of the four-digit NAICS industries that compose the US manufacturing sector. While these data are more aggregated than we would like, they have three virtues: (1) They provide comprehensive coverage of the manufacturing sector; (2) they are measures of value added rather than final output and by excluding input costs capture precisely the variable that is directly related to industry wages and profits; and (3) they can be matched with estimates of multifactor productivity growth that have been calculated by the Bureau of Labor Statistics (BLS) and skills as indicated by employment shares of production and nonproduction workers.

\section{Import-Share Weighted Prices}

Using manufacturing imports trade data at the four-digit NAICS level for all industries except refined petroleum we aggregate the value-added price deflators, weighting them by the average share of each industry in US manufactured imports from developing and industrial countries between 1997 and $2006 .{ }^{26}$ The relative domestic prices in industries with high shares of developing-country imports appear to mirror those of import prices. As reported in table 1, between 1987 and 2006, the developing-country manufactured import-weighted price series declines by $45 \log$ points relative to the developed country import weighted series. While not strictly comparable to the manufacturing import price

\footnotetext{
${ }^{25}$ There were similar declines in import prices from developing countries relative to US nonagricultural export prices (Edwards and Lawrence 2010, chapter 2).

${ }^{26}$ NAICS trade classifications have only been used since 1997.
} 
series because of weighting differences, the decline in this relative domestic price measure between 1990 and 2006 of $41 \log$ points is even greater than the $25.3 \log$ point drop in the ratio of manufactured import prices from developing countries to those of manufactured import prices from industrial countries shown in figure 1.

Factor prices such as real product wages will reflect not only product prices but also productivity. In addition to product prices, therefore, productivity changes should be accounted for. Accordingly we use the matched BLS data on multifactor productivity growth to estimate changes in "effective prices" i.e., price changes plus productivity changes. As reported in table 1 (row 3 ) we therefore subtract the inverse of the log of relative productivity growth from the relative price changes to estimate changes in effective prices. Productivity growth was especially high in sectors with declining prices and as a result effective prices suggest wage pressures that are far more muted than if the relative prices were assumed to be the only determinant of wages. The relative developing to industrial country import-weighted measure of effective domestic prices still has a downward trend but the decline between 1987 and 2006 is just $6 \log$ points (compared with $45 \log$ points for prices alone, see table 1). 


\section{Box 1 Defining skilled and unskilled labor}

In this study we use the classification of US workers into production and nonproduction workers as our measure of skills because it allows us to use more disaggregated industry data. The US input-output tables used in the study match trade and employment for manufacturing at the four-digit NAICS, which divides manufacturing into 88 different industries. This is the most disaggregated level for which data on worker educational levels is available. More disaggregated census data are also available for manufacturing at the six-digit level, which reports on 470 different industries. This is a high level of disaggregation. ${ }^{27}$

We can exploit this data by using census employment measures of production and nonproduction workers as our proxy for "skilled" and "unskilled" workers. This measure is not ideal because it includes some relatively poorly paid white collar office workers-educational attainment measures might be preferred-but it does have the virtue of being available at both the four-and six-digit NAICS level. ${ }^{28}$ Moreover distinguishing between production and nonproduction workers segments the manufacturing labor force into groups with shares and wages that are not very different from a classification system based on education. For example, in 2005 production worker wages were 65 percent of the wages of manufacturing nonproduction workers. In the same year, the weekly wages of full-time male and female workers with a high school degree were 60 and 62 percent of male and female workers with college degrees.

Similarly, the percent of manufacturing employment with a college degree is quite similar to the percent of employment of nonproduction workers.

\section{Skill-Share Weighted Prices}

But do these price changes translate into declining prices of relatively unskilled laborintensive products? To answer this question we weight the value added and productivity measures by employment shares of production and nonproduction workers - our proxy for skill intensity. ${ }^{29}$ We use census data and average industry employment shares for 1997, 2002, and 2007.

\footnotetext{
${ }^{27}$ On average in the years 1997, 2002 and 2007 the typical six-digit industry had 31.7 thousand employees.

${ }^{28}$ In 2007 production workers accounted for 71 percent of manufacturing employment. On average, production worker wages at $\$ 37,512$ were 57.6 percent of the $\$ 65,083$ earned by nonproduction workers. ${ }^{29}$ Skill intensity can be measured either by numbers of workers, the ratio of production to nonproduction (prod/nprod), or by the shares paid to each type of worker in value added (sprod/snprod). For the purposes of linking product and factor prices in the Stolper-Samuelson theory the cost shares measures are more appropriate and those are used in these data.
} 
Weighting by skill produces surprising results. Between 1987 and 2006, this price measure actually increases by $13 \log$ points more when weighted by production worker shares than it does when weighted by nonproduction worker shares (table 1). In contrast to the impression left by the import-weighted price shares, therefore, this result appears to imply pressures for greater wage equality! Again these pressures are more muted when productivity changes are accounted for. Weighted by employment shares, relative effective prices of production to nonproduction workers rise by just 2 percent over the entire period (compared with the 13 percent increase in the price deflators). In this case there appear to be smaller pressures for increased wage equality - although the StolperSamuelson theory does indicate a "magnification effect" depending on relative factor shares that could be quite large if these shares are relatively close. ${ }^{30}$ The contrasting trends in the import and skill weighted series is vividly captured in figure 2.

The differences in the effective relative price trends when imports and employment shares are used as weights highlight the key problem with the presumption that US industries with high shares of imports from developing countries are relatively intensive in unskilled labor. As indicated in table 2, this key presumption in the HOSS story is not borne in the data. In fact, US industries with high shares of imports from developing countries are relatively skill intensive! When weighted by developing-country import weights, (we use average shares between 1997 and 2007) the share of production workers in the average industry wage bill of 55 percent is actually lower than when weighted by developed-country import weights (60 percent). Both are considerably lower than the share of production workers in the overall wage bill for manufacturing (71 percent). This indicates that products that are traded tend generally to be more skill intensive.

\section{Measurement Error}

\footnotetext{
${ }^{30}$ Using a * to indicate proportional rates of change, and $S x$ and $S y$ are the shares of skilled labor in the production cost of $x$ and $y$ respectively the theory indicates that $P x^{*}-P^{*} y=(S x-S y)\left(W s^{*}-W u^{*}\right)$. This implies larger changes in wages for any given relative price changes when $S x-S y$ is small, so long as both products continue to be produced.
} 
Before we reject the HOSS, however we need to consider two possible sources of measurement error that could affect this result. First, when the BLS measures some prices and particularly those of computers and electronics products it makes distinctive "hedonic" adjustments for quality improvement. If these are mismeasured, the rapidly declining prices (and rapidly rising productivity growth) recorded for these products could be inaccurate and contaminate the results. And second, there could be aggregation bias from using data at the four-digit level. These data could submerge more refined industrial categories, which are unskilled labor intensive within larger categories in which skilled labor dominates. In what follows, therefore, we explore these issues, first by excluding the computer sector from the results, and second by providing estimates of price behavior and skill intensity using available six-digit NAICS data.

\section{Computers and Electronics}

We can isolate the role of computers and electronics products in the domestic price and productivity outcomes. The price declines have been quite astonishing. In 1987, for example, prices of computers NAICS 3341 and semiconductors NAICS 3344 were 2,446 and 650 percent higher than in 2006 and prices for communications (3342), audio (3343), and optical equipment (3346) also have strong downward trends. At the same time multifactor productivity growth has been very rapid. Productivity in 2006 was 20.5 and 12.5 times higher in computers and semiconductors, respectively, than it was in 2006.

Dropping the measures of the six four-digit 334 sectors from our sample produces some interesting changes and reveals again the large role that these observations play in the results. The effects can be seen in table 3. Excluding these variables leaves us with very small effects. Instead of a $45 \log$ point decline between 1987 and 2006, the decline in the relative import-weighted domestic price series is now only $4 \log$ points for the period as a whole - all of which is completed by 1995. The decline in effective prices is just 3 percent and again the measure is unchanged between 1995 and 2006. Similarly, instead of a 13 percent rise in relative production worker-weighted prices, these prices fall, but by just 1 percent over the entire period. Effective relative skill-weighted prices remain almost constant throughout the period. Indeed what is so striking about these 
results particularly for the period after 1995, for which the weights are more relevant, is how small the changes in both relative prices and relative effective prices are. All told, therefore, if the computer sectors are excluded from the data, the overall price changes do not mandate changes in the relative wages of skilled workers.

Dropping the computer sector lowers the estimated skill content of imports from both developed and developing countries and brings them closer together, but as reported in table 2, industries with high shares of imports from developing countries remain slightly more skill intensive than those with high developed-country import shares. Even without NAICS 334, therefore at the four-digit level, there is no support for the Heckscher-Ohlin presumption that imports from developing countries occur in industries that are more intensive in unskilled labor.

Should the computer industry be included in data? In an earlier debate, Jeffrey Sachs and Howard Shatz (1994) were critical of Lawrence and Slaughter (1993) for including it. They argued that measurement error was so rife in the prices of these products - they are measured using hedonic price regressions - and their behavior such an outlier that they should not be included. ${ }^{31}$ If we follow this advice and exclude computers and electronics, there is little to suggest that recent domestic price movements have mandated lower wages for unskilled workers.

On the other hand, by excluding computers and electronics we could be overlooking an important source of wage pressures. The sector does, after all, account for a third of all manufactured imports from developing countries and a high share of US manufacturing productivity growth. Including the data for computers and electronics indicates that the relative prices of skill-intensive industries have fallen-which ceteris paribus would be good for unskilled wages - but that these price pressures have been offset by rapid productivity growth. Both with and without computers, therefore, the implication - consistent with actual wage behavior - is that in recent years, trade is not a major source of increasing US wage inequality.

\section{Aggregation}

\footnotetext{
${ }^{31}$ It is certainly well recognized that because prices are changing so rapidly, fixed weight indexes give results that are very sensitive to the base year that is used. For this reason, chain-weighted indexes are now used in the US national income accounts.
} 
Paul Krugman (2008) noted the strange coincidence of high skill intensity and large developing-country shares in imports in the computer and electronics industry and cited it as an example of the aggregation bias that confounds those who believe that developingcountry trade has caused substantial wage inequality. The problem is that some parts of some industries might be relatively less skill intensive but submerged in the aggregate data of more skill-intensive sectors.

Is this concern warranted? There are data available at the six-digit NAICS for producer prices and production and nonproduction worker employment. This is a high level of disaggregation with average employment in each six-digit industry of about 30,000 workers. But the data are not ideal. First because producer prices include the cost of inputs not produced in each industry and second because price measures should be adjusted for productivity growth.

Currently, 456 Producer Price indexes are available at the six-digit NAICS level. Unfortunately, however, some of these have only been introduced recently (after 2003). We were, however, able to obtain continuous measures for about 280 price indicesexcluding refined petroleum - that are available back to 1994. These accounted for about 70 percent of all US manufactured imports in 2000 . We weight these prices by the average shares of developing- and developed-country imports and production and nonproduction worker shares between 1997 and 2006.

As shown in figure 3, we obtain results that are qualitatively similar but more extreme than those at the four-digit level suggesting that aggregation does dampen some of the differences. When the computer and electronics industries are included in the data, the downward trend in the relative developing-country import-weighted producer prices is even stronger than the decline in similarly trade-weighted four-digit deflators. Between 1994 and 2006, the years for which we have overlapping data, the relative importweighted producer prices decline by $44 \log$ points compared to the $32 \log$ point percent decline in the correspondingly weighted four-digit price deflator measure. Prices weighted by production worker employment shares increase by $15 \log$ points relative to prices weighted by nonproduction worker shares. This is also more than twice the $11 \mathrm{log}$ point increase over the same period with similarly weighted four-digit deflators. 
While larger price pressures are uncovered by disaggregation, therefore, again the price pressures from developing-country imports do not translate into price pressures in sectors with high shares of production workers. Further disaggregation of the data therefore does not provide evidence for the substantial wage impacts expected by Krugman.2008

Computer prices influence this result, too. Excluding the 29 6-digit 334 industries, the relative developing/developed import weighted declines are $9 \log$ points rather than $44 \log$ points. This compares with the drop of just 1 percent for the similarly weighted four-digit deflators when computers are excluded. After dropping the 334 industries, the relative production worker prices no longer rise but instead now do decline over the period (i.e., by $3 \log$ points between 1994 and 2008). Thus, when computers and electronics are excluded, the downward import-weighted producer price pressures do translate into some increased inequality along the lines of skills but it is just three log points over the 14-year period.

Further disaggregation also does not resolve the apparent paradox of the similarity in the skill composition of US imports from developing and developed countries. Weighted average payroll calculated using developing- and developed-country import shares at the six-digit levels yield very similar shares to those in table 2. In both cases, the developing-country import-weighted payroll share of production workers is actually lower than the developed-country import-weighted share. It is 54.6 versus 60.3 percent in the case of the four-digit measure and 51.2 versus 54.8 percent for the six-digit measure. ${ }^{32}$

Computers and electronics products do make a difference in these unexpected results although, unlike the price data, we have no reason to exclude the wage and employment data from these industries on the grounds of measurement error. Without the computer and electronics industries, it does appear that imports from developing countries are relatively intensive in unskilled labor. The production worker payroll share,

\footnotetext{
${ }^{32}$ An alternate measure of factor intensity is to use employment shares rather than payroll shares. We have weighted the skills intensity measure (share of production workers in employment) of 373 6-digit NAICS industries that we can match with trade data for imports from developing and industrial countries. These indicate that for the period 1994 to 2008 it makes no difference to average skills intensity whether imports from developing or developed countries are used as weights. In both cases the weighted average production worker employment share was 64.4 percent, significantly lower than the 71 percent share in US manufacturing as a whole.
} 
when weighted by developing-country imports of 59.7 percent, is higher than the 56.4 percent share using developed-country import weights.

In sum, abstracting from the computer sector there is justification using disaggregated data for the presumption that manufactured goods imported from developing countries are less skill intensive than those imported from developed countries. But the differences are remarkably small and certainly not in line with conventional Heckscher-Ohlin theory. Remarkably, therefore, even at the six-digit level the supposition that US imports from developing countries are disproportionately concentrated in industries in which unskilled workers account for a relatively high share of wage bill is not evident in the data.

This finding has important methodological implications. It suggests that even at the most disaggregated level feasible, net factor content of trade analysis using recent data will not indicate that trade induced large changes in relative wages. Indeed since we have considered only the direct factor inputs, input-output analysis, which takes account of inputs from other industries, is likely to show even smaller differences in factor intensity.

There are several ways of understanding these results but none are consistent with the HOSS story. One possibility, which is at odds with Heckscher-Ohlin theory, is that imports from developing countries are actually skill intensive. A second is that production processes are different, i.e., there are factor intensity reversals and goods produced using unskilled labor relatively intensively in developing countries are produced in the US using skilled labor-intensive methods. But this would imply that declining relative import prices from developing countries are actually a force for increased wage equality! The third possibility is that even at highly disaggregated classifications, the goods imported from developing countries are quite different from those made in the USA. This possibility would imply that once the economy becomes specialized, import prices have quite muted impacts on relative wages in US manufacturing.

\section{Section IV: Isolating the Impact of Trade Prices with Mandated Wage Regressions}


Prices and productivity in a large country such as the United States are outcomes of a range of domestic ( $R \& D$, tastes, imperfect competition) as well as international forces (tariffs, foreign prices, commodity cycles, international transport costs). It is, therefore, possible that price pressures from developing countries have been a force for wage inequality, but these pressures have been offset by changes in other variables that influence US value-added prices and productivity. There is always the possibility that "but for trade" US wage inequality might have fallen.

In this section, we deal with this concern and isolate the contribution of developing-country trade to changes in wages using US import unit values and tariffs. The analysis follows Feenstra and Hanson (1999) and is conducted in two steps. The first stage isolates the impact of imports on US effective prices (value added plus productivity) using four-digit NAICS level data. This is done by regressing effective prices on import unit values and tariff rates associated with US imports from developed and developing countries. Other structural determinants such as investment in information capital stock, capital intensity, and skill intensity are also included in the specification. $^{33}$

The second stage uses these estimated price changes to determine the relative wage changes mandated by these import price changes. This is done by regressing the predicted change in effective price associated with import unit values on factor cost shares (three factors are used: production workers, nonproduction workers, and capital). ${ }^{34}$ The estimated coefficients can be interpreted as the change in the return to labor and

\footnotetext{
${ }^{33}$ The equation we estimate is specified as: $\Delta \log P_{j t}+\Delta \log T F P_{j t}=\sum Z_{k, j t} \delta_{k}+v_{j t}$ where $P$ denotes value-added price, $T F P$ denotes total factor productivity, $v_{j t}$ is the random error, and the estimated coefficients $\delta_{k}$ capture the contribution of the structural variables $Z_{k}$ to changes in effective prices. In effect, this equation is the reduced form of separate price and total factor productivity equations (see Feenstra and Hanson 1999). Feenstra and Hanson (1999) use a variable termed "effective TFP" in their effective price measure. This is calculated as the primal measure of TFP plus the average deviation of industry-specific factor price changes from their mean levels. We do not have wage data by production and nonproduction worker for the entire period and therefore use only the primal measure of TFP.

${ }^{34}$ The second-stage regression is specified as: $\hat{\delta}_{k} Z_{k, j t}=\sum_{\mathrm{i} \in \mathrm{I}} \theta_{i j t} \beta_{k, i}+\varepsilon_{k, j t}$ where $\theta_{i j}$ is the share of factor $i$ (production worker, nonproduction worker, capital) in the average cost of producing one unit of value added of product $j$. The coefficient $\beta_{k i}$ is interpreted as the change in price of primary factor $i$ that can be attributed to the structural variable $Z_{k}$. The mandated wage analysis is strictly imbedded in the StolperSamuelson theoretical framework where factors are mobile across sectors such that the zero profit condition is maintained in each sector. Our focus is therefore on identifying the long-run effect on wages from changes in prices of competing imports.
} 
capital mandated by changes in the price of competing imports. We also estimate the changes in factor returns mandated by changes in US tariff rates imposed on developing and developed countries.

The mandated wage approach has been widely used to isolate the effect of developing-country trade on US wages (Leamer 1998, Feenstra and Hanson 1999; Haskel and Slaughter 2003). Where our study differs from these is that we use direct measures of import competition, namely import unit values, as our explanatory variables. Other studies have used quantitative measures of import intensity or technology (Feenstra and Hanson 1999) or measures of tariff and transport costs (Haskel and Slaughter 2003) to explain wage inequality. ${ }^{35}$ To some extent these are indirect measures of international competition.

The mandated wage regressions corroborate the earlier analysis that finds a minor impact of developing-country trade on US wage inequality. The price regressions reveal a small but statistically significant association between US effective prices and international prices and US tariff rates. However, the sector bias of import prices, including those from developing countries as a group, from 1993 to 2006 mandated no change in US wage levels or wage inequality.

One explanation for this finding is that price changes within developing countries offset each other. For example, our estimates indicate that Chinese import prices mandated a rise in the total return to labor and a slight increase in wage inequality, but these effects were offset by price movements from other developing countries. An implication drawn from the results is that developing countries do not have equivalent effects on wage inequality in the United States. But overall, the regression analysis suggests that trade-induced domestic price changes are not a cause of rising wage inequality in recent years.

\section{Skill Bias of US Import Prices}

\footnotetext{
${ }^{35}$ An exception is the study of Haskel and Slaughter (2001) who include import prices for the OECD, Newly Industrialized Countries (NICs), and the non-OECD rest of the world in their wage regressions for the United Kingdom. Their international price variables are unable to explain any of the rise in UK wage inequality experienced during the 1980s.
} 
We are primarily interested in whether import price competition from developing countries has raised wage inequality in the United States over the past decade. Ideally we would want to use import price indices as the measure of import price competition. Unfortunately, the available NAICS-classified import price indices constructed by the Bureau of Labor Standards only cover a short period. We therefore construct Tornqvist indices at the four-digit NAICS level for the period 1993-2006 using highly disaggregated (10-digit HTS) US import unit values. ${ }^{36}$ Unit value indices are constructed for a developed-country group, China, Mexico, an Asian grouping (Malaysia, Singapore, Korea, Thailand, Indonesia, Taiwan, and Philippines), and other developing countries. China and Mexico are included separately as they both account for a relatively high proportion of US imports (more than 10 percent after 2000). ${ }^{37}$

As a consistency check, we first plot relative price indices for the selected countries and country groupings. Figure 4 presents the log ratio of the weighted average import price of production worker-intensive sectors relative to nonproduction workerintensive sectors with the index value for 2006 set equal to one (i.e., the log of the index equals zero in 2006). The average share of production workers and nonproduction worker wage costs in value added for 1997, 2002, and 2007 are used as weights. Declining relative price indices would be consistent with rising wage inequality from trade in the United States.

The relative price indices reveal substantial variation in the skill bias of import prices with no consistent relationship across developing countries. Import unit values from Mexico and other developing countries rose in production worker-intensive sectors

\footnotetext{
${ }^{36}$ The data are sourced from the Center for International Data. See Feenstra, Romalis, and Schott (2002) for a discussion on the data. The data are first converted to time-consistent HTS codes using the code provided in Pierce and Schott (2009). We then exclude the top and bottom 1 percent of data to remove outliers. Further, new products are included in the Tornqvist index, but we do not adjust for the biases that the entry of new products and exit of old products have on the index (see Feenstra 1994 and Broda and Weinstein 2008).

${ }^{37}$ Developed countries are made up of high-income countries as defined by the World Bank's Country Classification. One limitation of our measure of import price competition is that unit values are not true price indices in that changes in the composition and quality of imports can change the calculated unit value even if product prices are unchanged. A second concern is that errors in the measurement of value or quantity of trade data introduce errors into the unit value measures. We attempt to overcome some of these limitations by using highly disaggregated trade data, but heterogeneity in prices across countries and measurement errors are evident even at this level of disaggregation (see Schott 2004).
} 
relative to nonproduction worker-intensive sectors implying pressures for declining wage inequality over the period as a whole. ${ }^{38}$ In contrast, trends in unit values for imports from China and developed countries imply pressures for rising wage inequality, but the magnitude of the difference in weighted average prices from 1996-2006 is very small (equivalent to 2 log points). For developing countries, as a whole, trends in import prices (unit values) in production worker-intensive sectors appear to be no different from nonproduction worker-intensive sectors.

In sum, the sector bias of import prices from developing countries as a whole appears to be too small to have effected substantial changes in US wage inequality in recent years. But the trends also reveal that the wage effect of import competition in the United States is not necessarily equivalent for all developing countries.

\section{Import Competition and US Effective Prices}

To isolate the impact of these import price changes on US wages we first need to determine the extent to which they alter US prices. If import prices have little impact on the price received by US producers, then it is unlikely that they will substantially change US wages, irrespective of their sector bias.

Table 4 presents the results of various price regressions using four-digit NAICS data over the period 1993-2006. The dependent variable is calculated as the log change in value-added prices plus total factor productivity growth, using data obtained from the BLS multifactor productivity database. Because the dependent variable in the price equation includes total factor productivity growth, our estimates, to some extent, deal with the argument by Wood (1994) that firms respond to import competition by upgrading capital and improving productivity (termed "defensive innovation").

The independent variables include the log change in import prices, the log change in US import-weighted average tariffs imposed on developed and developing countries, and various other controls for other factors influencing US prices. These controls include the ratio of production workers to nonproduction workers, the capital-labor ratio, and the

\footnotetext{
${ }^{38}$ The volatility of the price ratio for Mexico is a result of volatile price changes in the NAICS sector 3364 (aerospace products and parts), which is relatively skill intensive. Few products are imported from this sector leading to large movements in price changes.
} 
share of information capital stock in total capital stock (in 2000 prices at two-digit NAICS level). Finally, sector dummy variables are included to capture time-invariant sector effects and two-digit NAICS by year interaction dummy variables are used to account for sector invariant time effects at the two-digit level.

The price equation performs well. The first column of results presents the coefficients of a basic regression where US effective prices are regressed on aggregate import unit values, US tariffs, and the various controls. Close to 47 percent of the variation in effective prices is explained by the regression and the sign on the import unit values is positive as expected. A 10 percent rise in aggregate import prices is associated with a 1.8 percent rise in US effective prices. Tariff protection also raises effective prices, but only if imposed on trade from developing countries. A 1 percent reduction in tariffs, calculated as $\ln (1+$ tariff rate), on developing-country imports is associated with a 0.54 percent decline in US effective prices. Our tariff variable is a measure of protection on output, so this outcome is expected. ${ }^{39}$

Our primary interest is the relationship between US prices and developingcountry trade. Accordingly, column 2 and 3 in Table 4 disaggregate US import unit values into developed- and developing-country components. Once again, the signs of the coefficients are as expected: import prices from both developed and developing countries are positively correlated with US effective prices (column 2). Further disaggregation (column 3) reveals significant coefficients for US import unit values from China and other developing countries but insignificant coefficients for Mexico and the Asian group. The size of the coefficient on developed countries (0.146) is large compared to China (0.037) and other developing countries (0.033), but this is to be expected as the group of high-income countries account for between 56 to 75 percent of US manufacturing imports used in our analysis. ${ }^{40}$ Overall these results suggest that US domestic products are closer (but imperfect) substitutes from goods imports from developed countries than they are for goods imported from developing countries. A theme we will develop more fully in the next chapter.

\footnotetext{
${ }^{39}$ Unfortunately, we do not have an indicator of tariff protection on intermediate inputs. As implied by Grossman and Rossi-Hansberg (2008) tariff liberalization that reduces the cost of intermediate inputs is expected to have a positive impact on effective prices.

${ }^{40}$ The coefficient combines the effect of the import share and the elasticity.
} 
In the fourth column, we exclude the computer sector (NAICS 334) because of the rapid changes in price and productivity experienced within that sector. The results hardly change. Column 5 includes additional variables for the interaction of import price changes with a measure of the skill intensity of production. These interaction terms allow for differential impacts of import price changes on effective prices across sectors. Some changes in coefficients are evident. The positive impact of Chinese prices on effective prices is stronger in skill-intensive sectors. The coefficient on Mexican import unit values is now positive, but the effect declines as the skill intensity of the sector rises. The coefficients on import unit values from high-income countries and other developing countries remain positive and rise slightly.

These price equations establish a mechanism through which international competition influences the effective return to US producers. ${ }^{41}$ US effective prices are found to be responsive to changes in the border price of imports, whether originating from changes in the foreign selling price of competing goods or from changes in US tariff rates. What remains is to establish whether changes in foreign prices gave rise to economically significant changes in US wages.

\section{Mandated Wages}

In the second stage, we estimate changes in wages and the return to capital that can be attributed to import prices. The mandated wages are obtained by regressing the predicted changes in US effective prices associated with import prices on factor cost shares. The estimation approach therefore requires data on remuneration to workers and capital as a share of value added. Unfortunately, we are unable to obtain data at the four-digit NAICS level on the share of production and nonproduction workers in wage remuneration over the entire 1993-2006 period. We therefore construct average labor cost shares (of value added) using US Census data for 1997, 2002, and 2007. The share of capital remuneration in value added is calculated as the residual (i.e., 1- wage bill share of value

\footnotetext{
${ }^{41}$ Strictly speaking we have identified the association between US effective prices and international prices. If foreigners price to market, then it is possible that the foreign prices are endogenous resulting in various endogeneity biases when estimating the relationship. In addition, it is possible that an unobserved third factor may be driving the association. We are therefore circumspect about attributing causality to the relationship.
} 
added). The predicted change in effective prices over the entire period 1993-2006 is then regressed on these factor shares.

The mandated wage regression results are presented in table 5. The first two columns present the percentage change in wages over the period 1993-2006 mandated by changes in US import prices from developed (high-income) countries (column 1) and developing countries (column 2). The remaining columns present the mandated wages based on the disaggregated price equation estimates in column 3 of table 4 .

The results reveal a fair amount of variation across countries. Looking at column 1, the sector bias of developed-country price changes from 1993-2006 mandated a 4.6 percent rise in the nominal wage of nonproduction workers and a 5.7 percent rise in the return to capital to maintain zero profits in all sectors. No change in the wage of production workers is mandated. Also presented in the table are the mandated changes in the skill and capital premium and their associated significance levels. The outcome of these results is that import prices from high income countries mandated a 4.75 percentage point rise in the skill premium in US manufacturing, although the data suggests that the premium is not significantly different from zero.

Looking at the results for developing countries, we find contrasting and offsetting effects on wages for different regions and countries. In particular, the effect of Chinese imports (column 4) in raising wage inequality (by 2.15 percent) is more than offset by the inequality reducing impact of imports from other developing economies (column 5) (4.27 percent) and the decline in mandated wages of nonproduction workers from tariff liberalization. Similarly, Chinese import prices into the US mandated a statistically significant rise in the return to labor relative to capital, but this was also offset by sectoral trends in US import prices from other developing economies.

Taken together therefore US imports from developing countries mandated no change in US wage inequality from 1993 to 2006. This outcome is also revealed by the insignificant changes in production and nonproduction worker wages mandated by changes in aggregate US import unit values from developing countries (column 2). ${ }^{42}$

\footnotetext{
${ }^{42}$ Similarly, estimates based on aggregate US import unit values calculated using all countries reveal no significant change in relative wages, but do reveal a significant rise in the return to capital relative to labor.
} 
The results raise some interesting challenges to the common bifurcation of the world into developed- and developing-country groups. In the period we analyze, 19932006, the composition of developing-country trade and the sector biases of price changes were not equivalent across countries leading to very different influences on US wages and wage inequality. The heterogeneity of developing-country trade flows to the US requires a more refined and disaggregated assessment of their impact on US wages than has commonly been applied in the past.

Our results also present an unexpected impact on US wages from Chinese import competition. The sector bias of Chinese import prices mandated a rise in wages of both production and nonproduction workers and only a minor and statistically insignificant increase in wage inequality. The surprising result here is the finding that Chinese imports have adversely affected capital-intensive sectors in the United States. It could be that while many people think of China as a relatively labor-intensive country, it is more appropriate to think of its production structure as capital intensive.

\section{CONCLUSIONS}

This analysis suggests that the fears of rising US wage inequality from developingcountry imports in recent years are unwarranted. While conventional trade theory makes such expectations plausible our investigation reveals they are far off the mark. At the most disaggregated level for which comprehensive skills data are available we have found that the US industries competing with developing country imports are not particularly intensive in unskilled labor. Moreover, the relative effective prices of the US industries that are unskilled labor-intensive have actually increased rather than decreased since the early 1990s. Changes in effective US prices from whatever cause have not mandated changes in relative wages. Neither have changes that can be ascribed to import prices mandated increases in wage inequality.

The lack of association at a highly disaggregated level between imports from developing countries and skill intensity is consistent with at least three different explanations: first, the Heckscher-Ohlin theory is wrong and developing countries have not actually specialized in goods that are unskilled labor intensive; second, there are 
factor-intensity reversals and the goods imported from developing countries are produced using unskilled labor-intensive methods in developing countries but using skill-intensive methods in the US; or third, developed and developing countries are basically producing different goods. Using 10-digit unit-value data we have found that the evidence supports the last interpretation (Edwards and Lawrence 2010 forthcoming, chapter 8). The goods exported by developing countries are highly imperfect substitutes for those produced by developed countries. This means that for the most part, unskilled US workers are not competing head to head with their counterparts in developing countries. It also suggests that methodological approaches to the question of trade and wages that measure the net factor content of trade or that assume that imports and domestic products and/or tasks are close substitutes rest on extremely shaky grounds. 


\section{REFERENCES}

Alt, James E., and Michael Gilligan. 1999. The Political Economy of Trading States: Factor Specificity, Collective Actions Problems and Domestic Political Institutions. In International Political Economy: Perspectives on Global Power and Wealth, eds. Jeffry Frieden and David A Lake. Belmont, CA: Wadsworth.

Bernard, Andrew B., Stephen J. Redding, and Peter K. Schott. 2007. Comparative Advantage and Heterogeneous Firms. Review of Economic Studies 74: 31-66.

Bernard, Andrew B., Stephen J. Redding, and Peter K. Schott. 2009. Multi-product Firms and Trade Liberalization. Revised version of National Bureau of Economic Research Working Paper 12782. Cambridge, MA: National Bureau of Economic Research.

Bernard, Andrew B., Stephen J. Redding, and Peter K. Schott. 2010. Multi-product Firms and Product Switching. American Economic Review, forthcoming.

Bernard, Andrew, J. Bradford Jensen, and Peter K. Schott. 2006. Survival of the Best Fit: Competition from Low Wage Countries and the (Uneven) growth of US Manufacturing Firms. Journal of International Economics 68, no. 1: 219-237.

Bivens, Josh. 2007. Globalization, American Wages and Inequality, Past, Present and Future. Economic Policy Institute Working Paper 279. Washington: Economic Policy Institute.

Broda, Christian, and John Romalis. 2008. Inequality and Prices: Does China Benefit the Poor in America? University of Chicago (mimeo).

Broda, Christian, and David Weinstein. 2006. Globalization and the Gains from Variety. Quarterly Journal of Economics 121, no. 2: 541-585.

Cline, William. 1997. Trade and Income Distribution. Washington: Peterson Institute for International Economics.

Deardorff, Alan V., and Dalia Hakura. 1994. Trade and Wages: What are the Questions? In Trade and Wages Leveling Wages Down? eds. Jagdish Bhagwati and Marvin Kosters. Washington: American Enterprise Institute.

Deardorff, Alan V., and Robert W. Staiger. 1988. An Interpretation of the Factor Content of Trade. Journal of International Economics 24, 1-2: 93-107.

Edwards, Lawrence, and Robert Z. Lawrence. 2010. Rising Tide: Is Growth in Emerging Economies Good for the United States? Forthcoming, Washington: Peterson Institute for International Economics. 
Feenstra, R. 1994 New Product Varieties and the Measurement of International Prices. American Economic Review 84:157-177.

Feenstra, Robert C., and Gordon H. Hanson. 1996. Foreign Investment, Outsourcing and Relative Wages. In The Political economy on Trade Policy: Papers in Honor of Jagdish Bhagwati eds. Robert C. Feenstra, Gene M. Grossman, and Douglas Irwin. Cambridge, MA: MIT Press.

Feenstra, Robert C. 2004. Advanced International Trade: Theory and Evidence. Princeton, NJ: Princeton University Press.

Feenstra, Robert C., and Gordon H. Hanson. 1999. The Impact of Outsourcing and HighTechnology Capital on Wages: Estimates for the US, 1979-1990. Quarterly Journal of Economics 114, no. 3: 907-940.

Feenstra, Robert C., and Gordon H. Hanson. 2000. Aggregation Bias in the Factor Content of Trade: Evidence from US Manufacturing. American Economic Review 90, no. 2: $155-160$.

Feenstra, Robert C., John Romalis, and Peter K. Schott. 2002. US Imports, Exports, and Tariff Data, 1989-2001. National Bureau of Economic Research Working Paper 9387. Cambridge, MA: National Bureau of Economic Research.

Freeman, Richard B. 1995. Are Your Wages Set in Beijing? Journal of Economic Perspectives 9, no. 3: 15-32.

Goldin, Claudia, and Lawrence F. Katz. 2007. Long-Run Changes in the Wage Structure: Narrowing, Widening, Polarizing. Brookings Papers on Economic Activity 2: 135-168.

Grossman, Gene, and Esteban Rossi-Hansberg. 2008. Trading Tasks: A Simple Theory of Offshoring. American Economic Review 98, no. 5: 1,978-1,997.

Haskel, Jonathan E., and Mathew J. Slaughter. 2001. Trade, Technology and UK Wage Inequality. Economic Journal 111, no. 468: 163-187.

Haskel, Jonathan E., and Matthew J. Slaughter. 2003. Have Falling Tariffs and Transportation Costs Raised US Wage Inequality? Review of International Economics 11, no. 4: 630-650.

Katz, Lawrence F. 2008. Comment on Trade and Wages Reconsidered. Brookings Papers on Economic Activity, Spring: 143-149.

Krugman, Paul R. 1995. Growing World Trade: Causes and Consequences. Brookings Papers on Economic Activity 1995, no. 1: 327-377. 
Krugman, Paul R. 2007. Trade and Inequality, Revisited. Available at http://voxeu.org (accessed June 15, 2007).

Krugman, Paul R. 2008. Trade and Wages, Reconsidered. Brookings Papers on Economic Activity, Spring 2008: 103-137.

Lawrence, Robert Z. 1996. Industrial and Labor Relations Review, April 49 (3). Book review of: Wood, Adrian. 1995. North-South, Trade, Employment, and Inequality: Changing Fortunes in a Skill-Driven World. Oxford: Oxford University Press.

Lawrence, Robert Z. 2008. Blue-Collar Blues: Is Trade to Blame for Rising US Income Inequality? Washington: Peterson Institute for International Economics.

Lawrence, Robert Z., and Mathew J. Slaughter. 1993. International Trade and American Wages in the 1980s: Giant Sucking Sounds or Small Hiccup? Brookings Papers: Macroeconomics 2: 161-226.

Leamer, Edward E. 1998. In Search of Stolper-Samuelson Effects On US Wages. In Imports, Exports and the American Worker, ed. Susan Collins. Washington: The Brookings Institution.

Mishel, Lawrence, Jared and Sylvia Allegreto. 2007 The State of Working America 2006/7. Washington and Ithaca, N. Y: Economic Policy Institute and Cornell University Press

Mayda, Anna Maria, and Dani Rodrik. 2002. Why Are Some People (and Countries) more Protectionist than Others? European Economic Review, 2005, 49, no. 6 (August): $1,393-1,691$.

Pierce, Justin R., and Peter K. Schott. 2009. Concording US Harmonized System Categories over Time. Center for Economic Studies Working Paper 09-11.

Sachs, Jeffrey D., and Howard J. Shatz. 1994. Trade and jobs in US manufacturing. Brookings Papers on Economic Activity, no. 1: 1-84.

Schott, Peter K. 2003. One Size Fits All? Heckscher-Ohlin Specialization in Global Production. The American Economic Review 93, no. 3: 686-708.

Schott, Peter K. 2004. Across-product Versus Within-product Specialization in International Trade. The Quarterly Journal of Economics 119, no. 2: 646-677.

Scott, Robert E., Thea Lee, and John Schmitt. 1997. Trading Away Good Jobs: An Examination of Employment and Wages in the US 1979-1994. Economic Policy Institute Briefing Paper. 
Sitchinava, Nino. 2008. Trade, Technology and Wage Inequality: Evidence from US Manufacturing 1989-2004. University of Oregon (mimeo).

Stolper, Wolfgang, and Paul Samuelson. 1941. Protection and Real Wages. Review of Economic Studies 9, no. 1: 58-73.

Thompson, Henry. 1997. Prices and Wages in Trade Theory. Auburn University (mimeo). Available at www.auburn.edu (accessed February 15, 2010).

Whalley, John, and Lisandro Abrego. 2000. Demand Side Considerations and the Trade and Wages Debate. National Bureau of Economic Research Working Paper 7674. Cambridge, MA: National Bureau of Economic Research.

Wood, Adrian. 1994. North-South Trade, Employment and Inequality: Changing Fortunes in a Skill-Driven World, Oxford: Clarendon Press.

Wood, Adrian. 1995. How Trade Hurt Unskilled Workers. Journal of Economic Perspectives 9, no. 3: 57-80. 
Figure 1: Ratio of developing to industrial country US manufactured import prices (Log $\underline{\text { Scale } 2008=0)}$

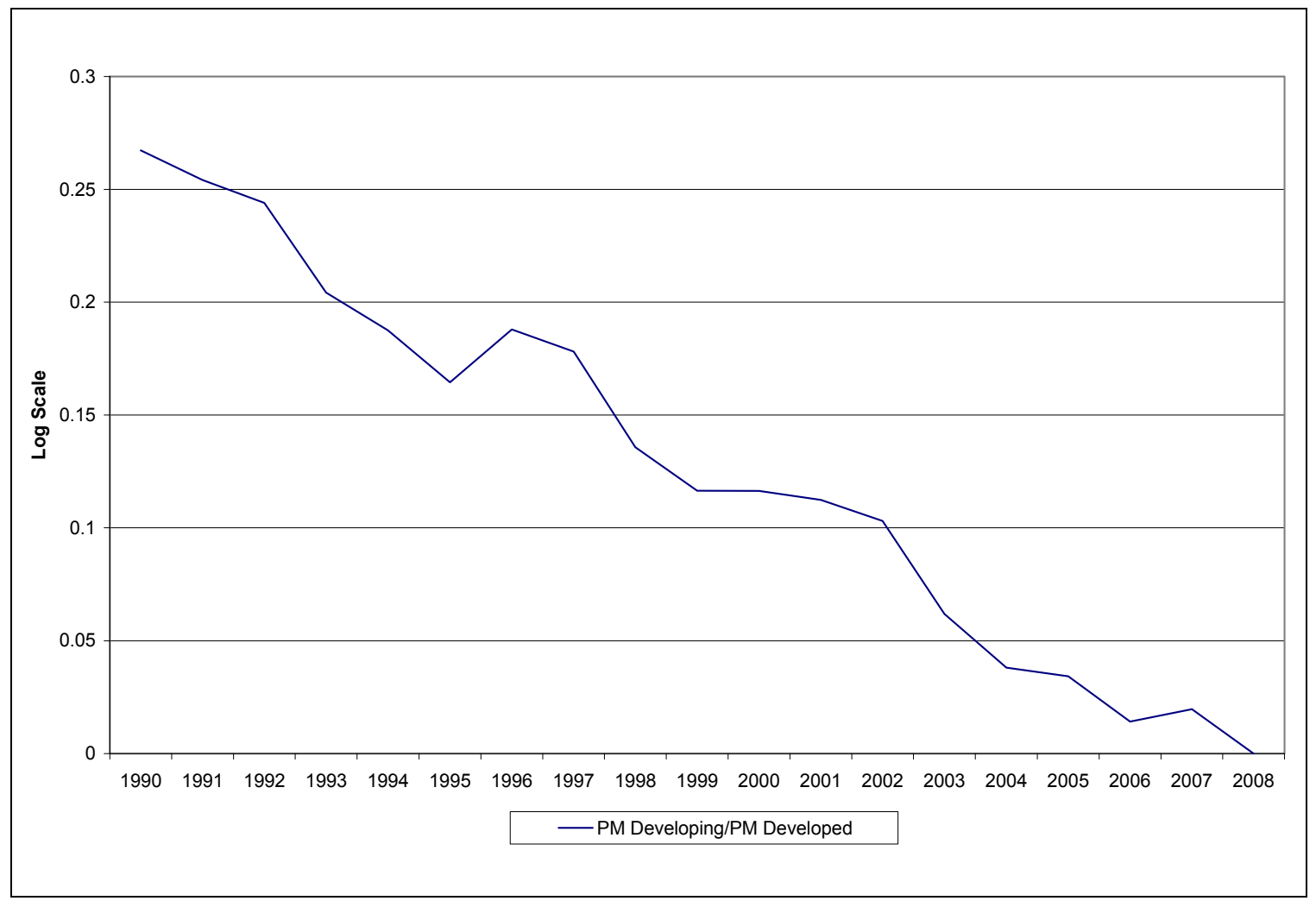

Source: Bureau of Labor Statistics Import Price Indexes. 
Figure 2: Trade and skill weighted relative effective prices (Log Scale $2006=0$ )

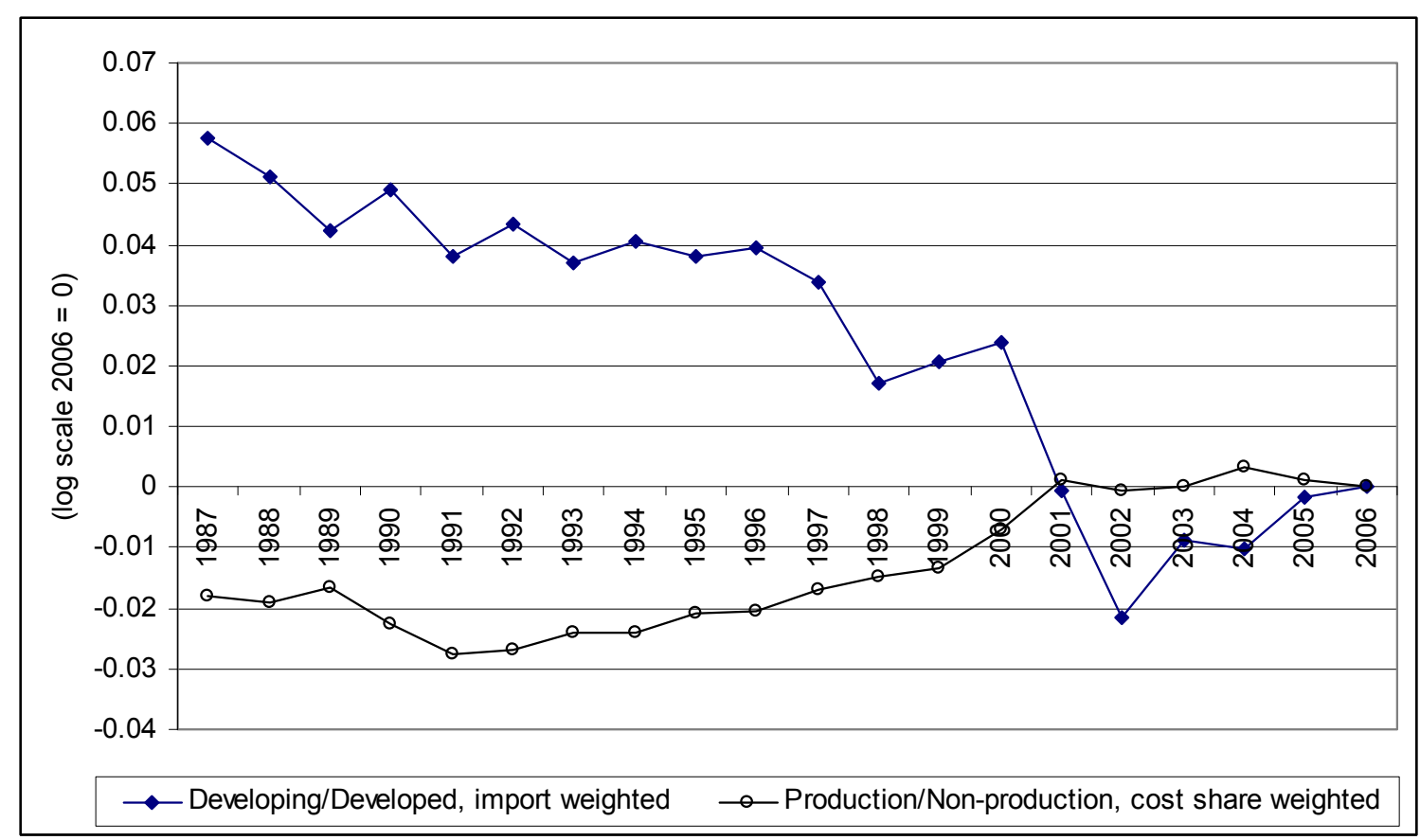


Figure 3: Import and skill-weighted 6-digit NAICS producer prices

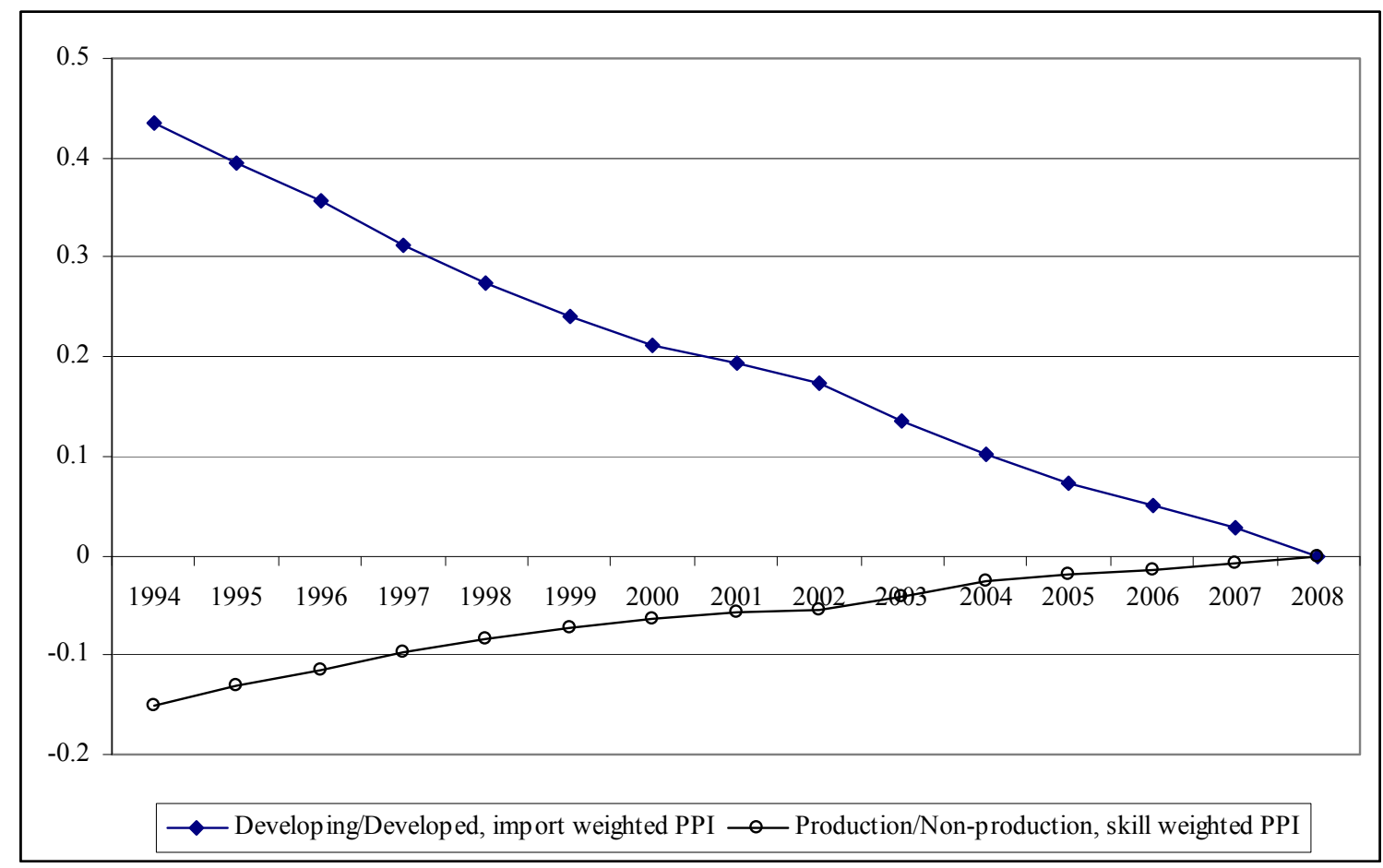


Figure 4: Production worker weighted import unit values relative to non-production worker weighted import unit values

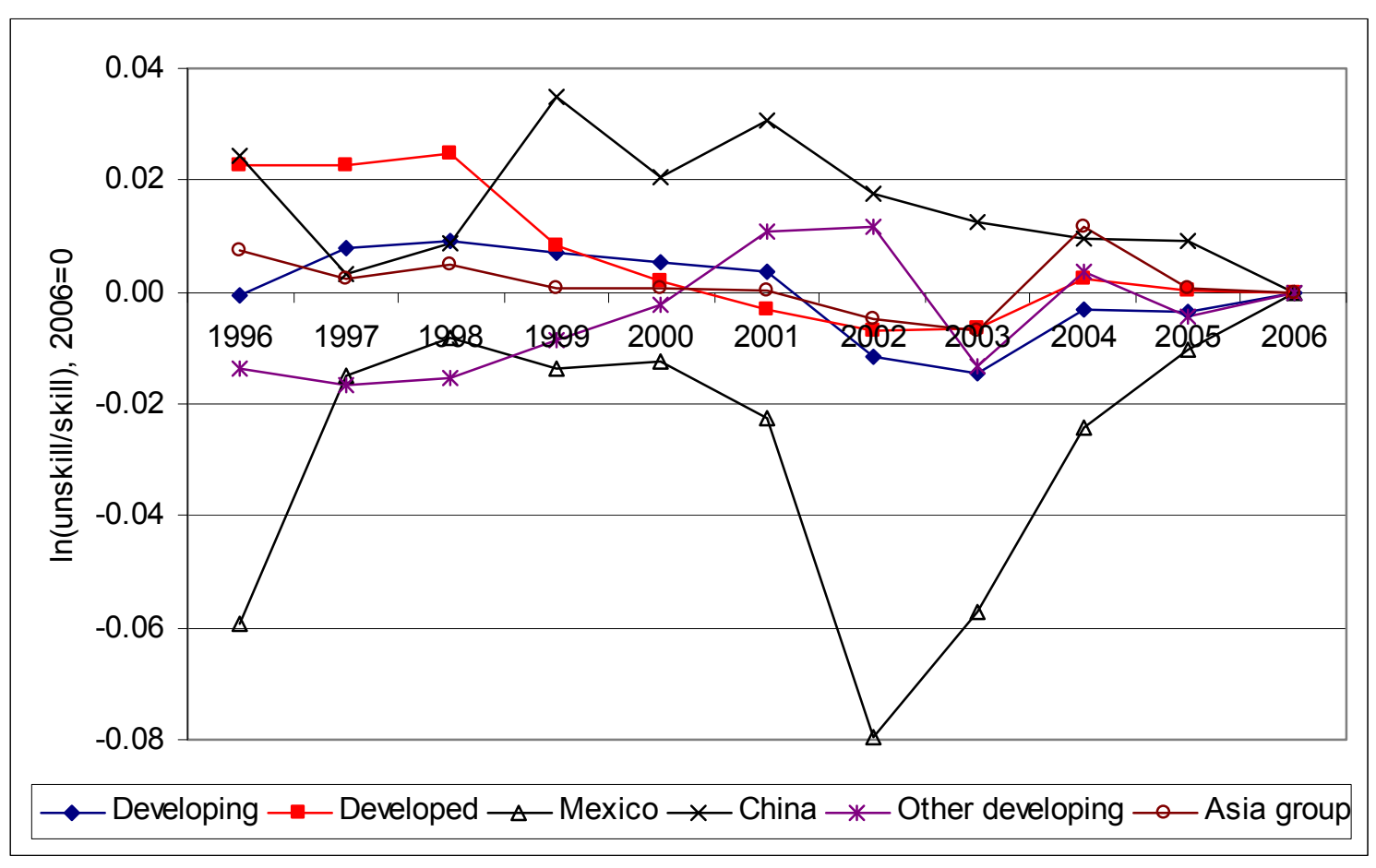


Table 1: Weighted relative effective prices, four-digit NAICS industries (Log Scale 2006

\begin{tabular}{|c|c|c|c|c|c|c|c|}
\hline & & 1987 & 1990 & 1995 & 2000 & 2005 & 2006 \\
\hline & \multicolumn{7}{|l|}{ Developing/Developed import weights } \\
\hline$(1)$ & Deflators & 0.45 & 0.41 & 0.28 & 0.12 & 0.02 & 0.00 \\
\hline$(2)$ & Multifactor Productivity (inverse) & 0.39 & 0.36 & 0.24 & 0.09 & 0.02 & 0.00 \\
\hline \multirow[t]{2}{*}{ (3) } & Effective prices (1) - (2) & 0.06 & 0.05 & 0.04 & 0.02 & 0.00 & 0.00 \\
\hline & \multicolumn{7}{|c|}{$\underline{\text { Production/Non-production employment weights }}$} \\
\hline$(4)$ & Deflators & -0.13 & -0.12 & -0.09 & -0.04 & -0.01 & 0.00 \\
\hline$(5)$ & Multifactor Productivity (inverse) & -0.11 & -0.10 & -0.07 & -0.04 & -0.01 & 0.00 \\
\hline (6) & Effective prices (4) - (5) & -0.02 & -0.02 & -0.02 & -0.01 & 0.00 & 0.00 \\
\hline
\end{tabular}

Source: BLS Multifactor Productivity Data, ITC Data Web.

LDC $=$ Average share of industry in US manufactured imports from developing countries 1997 to 2006

$\mathrm{DC}=$ Average share of industry in US manufactured imports from developing countries 1997 to 2006

Production $=$ Average share of industry in US Manufacturing Employment of Production Workers $(1997,2002$ and 2007)

Non- production $=$ Average share of industry in US Manufacturing Employment of Non Production Workers $(1997,2002$ and 2007) 
Table 2: Share of production workers in industry wage bill: (average 1997, $2002 \&$ 2007)

\begin{tabular}{lrrrr}
\hline & $\begin{array}{r}\text { Developing } \\
\text { country } \\
\text { weights }\end{array}$ & $\begin{array}{r}\text { Developed } \\
\text { country } \\
\text { weights }\end{array}$ & $\begin{array}{r}\text { Ratio } \\
\text { Developing/ } \\
\text { Developed }\end{array}$ & Manufacturing \\
\hline Total & 0.55 & 0.60 & 0.91 & 0.71 \\
Non-computers & 0.63 & 0.64 & 0.99 & 0.73 \\
NAICS 334 & 0.50 & 0.48 & 1.03 & 0.48 \\
\hline
\end{tabular}

Source: US Census of Manufactures

Developing country weights $=$ Share of industry in US manufactured imports from developing countries 1997-2007.

Developed country weights $=$ Share of industry in US manufactured imports from developed countries 1997 to 2007.

Non-computers $=$ excluding NAICS industries 3341 through 3345

NAICS $334=$ computers and electronics 
Table 3: Weighted relative effective prices without computers, Four-digit NAICS

industries excluding NAICS 334 (Log Scale 2006=0)

\begin{tabular}{lccccc}
\hline & $\mathbf{1 9 8 7}$ & $\mathbf{1 9 9 0}$ & $\mathbf{1 9 9 5}$ & $\mathbf{2 0 0 0}$ & $\mathbf{2 0 0 6}$ \\
\hline $\begin{array}{l}\text { Deflators } \\
\text { Developing/Developed }\end{array}$ & 0.04 & 0.03 & 0.00 & 0.01 & 0.00 \\
Production/Non-production & 0.01 & 0.01 & 0.01 & 0.00 & 0.00 \\
& & & & & \\
Effective prices & & & & & \\
Developing/Developed & 0.03 & 0.02 & 0.01 & 0.00 & 0.00 \\
Production/Non-production & 0.01 & 0.01 & 0.01 & 0.01 & 0.00 \\
\hline
\end{tabular}

Source: BLS Multifactor Productivity Data and ITC Data Web.

Developing $=$ Average share of industry in US manufactured imports from developing countries 1997 to 2006.

Developed $=$ Average share of industry in US manufactured imports from developing countries 1997 to 2006.

Production $=$ Average share of industry in US Manufacturing Employment of Production Workers (1997, 2002 and 2007).

Non- production $=$ Average share of industry in US Manufacturing Employment of Non Production Workers (1997, 2002 and 2007).

The following 4-digit NAICS industries are excluded: NAICS 3341, 3342, 3343, 3344, 3345 and 3346. 
Table 4: First stage determinants of US effective prices in manufacturing

\begin{tabular}{|c|c|c|c|c|c|}
\hline & \multirow[t]{2}{*}{ (1) } & \multirow[t]{2}{*}{ (2) } & \multirow[t]{2}{*}{ (3) } & \multicolumn{2}{|l|}{ (4) } \\
\hline & & & & $\begin{array}{l}\text { Exclude } \\
\text { Computers }\end{array}$ & $\begin{array}{c}\text { Incl. } \\
\text { Interactions }\end{array}$ \\
\hline$\Delta \ln ($ P Aggregate $)$ & $\begin{array}{r}\mathbf{0 . 1 8 1} \\
(0.033)\end{array}$ & & & & \\
\hline$\Delta \ln (\mathrm{P}$ Developed $)$ & & $\begin{array}{r}\mathbf{0 . 1 0 4} \\
(0.042)\end{array}$ & $\begin{array}{r}\mathbf{0 . 1 4 6} \\
(0.030)\end{array}$ & $\begin{array}{r}\mathbf{0 . 1 4 1} \\
(0.032)\end{array}$ & $\begin{array}{r}\mathbf{0 . 1 6 1} \\
(0.045)\end{array}$ \\
\hline$\Delta \ln (\mathrm{P}$ Developing) & & $\begin{array}{r}\mathbf{0 . 0 4 1} \\
(0.014)\end{array}$ & & & \\
\hline$\Delta \ln (\mathrm{P}$ China $)$ & & & $\begin{array}{r}\mathbf{0 . 0 3 7} \\
(0.015)\end{array}$ & $\begin{array}{r}\mathbf{0 . 0 3 8} \\
(0.015)\end{array}$ & $\begin{array}{l}-0.001 \\
(0.021)\end{array}$ \\
\hline$\Delta \ln (\mathrm{P}$ Mexico $)$ & & & $\begin{array}{r}0.008 \\
(0.008)\end{array}$ & $\begin{array}{r}0.011 \\
(0.008)\end{array}$ & $\begin{array}{r}\mathbf{0 . 0 3 5} \\
(0.013)\end{array}$ \\
\hline$\Delta \ln (\mathrm{P}$ Asia $)$ & & & $\begin{array}{r}0.008 \\
(0.019)\end{array}$ & $\begin{array}{r}0.001 \\
(0.017)\end{array}$ & $\begin{array}{r}0.020 \\
(0.030)\end{array}$ \\
\hline$\Delta \ln (\mathrm{P}$ Other Developing) & & & $\begin{array}{r}\mathbf{0 . 0 3 3} \\
(0.013)\end{array}$ & $\begin{array}{r}\mathbf{0 . 0 3 8} \\
(0.015)\end{array}$ & $\begin{array}{r}\mathbf{0 . 0 5 0} \\
(0.021)\end{array}$ \\
\hline$\Delta \ln (\mathrm{P}$ Developed $) \times$ skill/unskill & & & & & $\begin{array}{l}-0.029 \\
(0.078)\end{array}$ \\
\hline$\Delta \ln (\mathrm{P}$ China $) \mathrm{x}$ skill/unskill & & & & & $\begin{array}{r}\mathbf{0 . 0 8 1} \\
(0.046)\end{array}$ \\
\hline$\Delta \ln (\mathrm{P}$ Mexico $) \times$ skill/unskill & & & & & $\begin{array}{r}-\mathbf{0 . 0 4 2} \\
(0.018)\end{array}$ \\
\hline$\Delta \ln (\mathrm{P}$ Asia $) \times$ skill/unskill & & & & & $\begin{array}{r}0.043 \\
-(0.440)\end{array}$ \\
\hline$\Delta \ln (\mathrm{P}$ Other $) \times$ skill/unskill & & & & & $\begin{array}{l}-0.025 \\
(0.021)\end{array}$ \\
\hline$\Delta \ln ($ US tariff on Developed $)$ & $\begin{array}{l}-0.116 \\
(0.635)\end{array}$ & $\begin{array}{l}-0.217 \\
(0.685)\end{array}$ & $\begin{array}{r}-0.044 \\
(0.605)\end{array}$ & $\begin{array}{r}0.000 \\
(0.592)\end{array}$ & $\begin{array}{l}-0.003 \\
(0.614)\end{array}$ \\
\hline$\Delta \ln ($ US tariff on Developing) & $\begin{array}{r}\mathbf{0 . 5 4 9} \\
(0.213)\end{array}$ & $\begin{array}{r}\mathbf{0 . 5 8 0} \\
(0.214)\end{array}$ & $\begin{array}{r}\mathbf{0 . 6 0 1} \\
(0.268)\end{array}$ & $\begin{array}{r}\mathbf{0 . 6 8 6} \\
(0.251)\end{array}$ & $\begin{array}{r}\mathbf{0 . 6 7 2} \\
(0.244)\end{array}$ \\
\hline Skill/Unskill & $\begin{array}{l}-0.037 \\
(0.021)\end{array}$ & $\begin{array}{l}\mathbf{- 0 . 0 4 5} \\
(0.023)\end{array}$ & $\begin{array}{r}-0.030 \\
(0.021)\end{array}$ & $\begin{array}{r}-0.040 \\
(0.042)\end{array}$ & $\begin{array}{l}-0.030 \\
(0.021)\end{array}$ \\
\hline Information $\mathrm{K} /$ total $\mathrm{K}$ & $\begin{array}{l}-0.218 \\
(0.193)\end{array}$ & $\begin{array}{l}-0.234 \\
(0.192)\end{array}$ & $\begin{array}{r}-0.247 \\
(0.187)\end{array}$ & $\begin{array}{r}-0.237 \\
(0.194)\end{array}$ & $\begin{array}{l}-0.240 \\
(0.187)\end{array}$ \\
\hline $\mathrm{K} / \mathrm{L}$ ratio & $\begin{array}{r}\mathbf{0 . 2 0 0} \\
(0.097)\end{array}$ & $\begin{array}{r}\mathbf{0 . 2 0 5} \\
(0.099)\end{array}$ & $\begin{array}{r}\mathbf{0 . 1 8 8} \\
(0.094)\end{array}$ & $\begin{array}{r}\mathbf{0 . 3 6 8} \\
(0.133)\end{array}$ & $\begin{array}{r}\mathbf{0 . 1 9 5} \\
(0.095)\end{array}$ \\
\hline $\mathrm{N}$ & 1128 & 1123 & 1089 & 1005 & 1089 \\
\hline $\mathrm{F}$ & 4.79 & 4.6 & 5.05 & 5.13 & 5.15 \\
\hline r2 & 0.455 & 0.438 & 0.490 & 0.494 & 0.499 \\
\hline
\end{tabular}

Notes: The dependent variable is the log change in value added prices plus log change in total factor productivity. All estimation is over four-digit NAICS industries covering the period 1993-2006. Equations are weighted by the average industry share of the wage bill for each year.

Bold variables are significant at $10 \%$ level. Robust standard errors are in parentheses beneath the coefficients. Variable descriptions and sources are as follows:

K/L: Productive Capital Stock (Direct Aggregate-Billions of 2000 Dollars) per employee, 3-digit NAICS. Source: BLS.

Skill/unskill: Non-production workers/production workers, NAICS 4-digit. Source: BLS

$\Delta \ln$ (tariff): Log change in 1 plus import weighted average tariff rate (1+tariff), NAICS 4-digit: Source: own calculations using trade data from Feenstra et al. (2002).

Information K/total K: Information Capital stock/Total capital stock, NAICS 3-digit. Source: BLS 
Table 5: Mandated wages, 1993-2006

\begin{tabular}{|c|c|c|c|c|c|c|}
\hline & \multicolumn{2}{|c|}{$\begin{array}{c}\text { Based on column } 2 \\
\text { results of Table } 4\end{array}$} & \multicolumn{4}{|c|}{ Based on column 3 results of Table 4} \\
\hline & $\begin{array}{c}\Delta \ln (\mathrm{P} \\
\text { Developed }) \\
\quad(1)\end{array}$ & $\begin{array}{c}\Delta \ln (\mathrm{P} \\
\text { Developing }) \\
(2)\end{array}$ & $\begin{array}{c}\Delta \ln (\mathrm{P} \\
\text { Developed }) \\
(3)\end{array}$ & $\begin{array}{c}\Delta \ln (\mathrm{P} \\
\text { China }) \\
(4)\end{array}$ & $\begin{array}{c}\Delta \ln (\mathrm{P} \text { Other } \\
\text { developing }) \\
\quad(5)\end{array}$ & $\begin{array}{c}\Delta \ln (\text { Tariff } \\
\text { developing) } \\
(6)\end{array}$ \\
\hline Production worker & $-0.2 \%$ & $-0.3 \%$ & $-0.3 \%$ & $2.6 \%$ & $1.0 \%$ & $0.8 \%$ \\
\hline se & $(0.021)$ & $(0.011)$ & $(0.030)$ & $(0.013)$ & $(0.012)$ & $(0.010)$ \\
\hline Non-production worker & $\begin{array}{r}\mathbf{4 . 6 \%} \\
(0.023)\end{array}$ & $\begin{array}{r}2.4 \% \\
(0.018)\end{array}$ & $\begin{array}{r}\mathbf{6 . 4 \%} \\
(0.033)\end{array}$ & $\begin{array}{r}\mathbf{4 . 8 \%} \\
(0.023)\end{array}$ & $\begin{array}{l}-\mathbf{3 . 3} \% \\
(0.011)\end{array}$ & $\begin{array}{l}\mathbf{- 3 . 1 \%} \\
(0.017)\end{array}$ \\
\hline Capital & $\begin{array}{r}\mathbf{5 . 7 \%} \\
(0.017)\end{array}$ & $\begin{array}{r}1.5 \% \\
(0.009)\end{array}$ & $\begin{array}{r}\mathbf{8 . 0 \%} \\
(0.024)\end{array}$ & $\begin{array}{l}\mathbf{- 3 . 1 \%} \\
(0.013)\end{array}$ & $\begin{array}{r}3.5 \% \\
(0.010)\end{array}$ & $\begin{array}{r}-1.0 \% \\
(0.006)\end{array}$ \\
\hline $\mathrm{N}$ & 85 & 85 & 85 & 85 & 85 & 85 \\
\hline $\mathrm{F}$ & 36.99 & 13.07 & 37.03 & 10.07 & 11.2 & 14.84 \\
\hline $\mathrm{r} 2$ & 0.641 & 0.339 & 0.641 & 0.351 & 0.375 & 0.495 \\
\hline $\begin{array}{l}\text { Mandated change in relat } \\
\text { Wage Non- } \\
\text { production/Wage }\end{array}$ & e factor return & & & & & \\
\hline production & 4.75 & 2.67 & 6.67 & 2.15 & $-4.27 * *$ & -3.87 \\
\hline $\begin{array}{l}\text { Rental capital/Wage } \\
\text { production worker }\end{array}$ & $5.87^{*}$ & 1.73 & $8.23 *$ & $-5.71 * * *$ & 2.49 & -1.76 \\
\hline $\begin{array}{l}\text { Rental capital/Wage non- } \\
\text { production worker }\end{array}$ & 1.12 & -0.94 & 1.56 & $-7.86^{* *}$ & $6.76^{* * *}$ & 2.11 \\
\hline
\end{tabular}

Notes: Equations are weighted by the average industry share of the wage bill for each year. Bold variables are significant at $10 \%$ level. Robust standard errors are in parentheses beneath the coefficients.

The description and source of the data are as follows:

Capital cost share: Share of capital payments in value added. Capital share calculated as 1 - Lshare where Lshare is share labor remuneration in value added. Source: BLS data as used to calculate multifactor productivity.

Production worker cost share: Share of production worker payments in value added used as proxy for unskilled labor intensity of production. Calculated as: sprod* Lshare $_{t}$ where sprod is average share production workers remuneration in total wage bill based on 1997, $2002 \& 2007$ data obtained from Census Bureau. Non-production worker cost share is calculated as (1-sprod)*Lshare .

$* \mathrm{p}<0.1, * * \mathrm{p}<0.05$ and $* * * \mathrm{p}<0.01$. 